\title{
The social work voice - doxa and dissent in neoliberal times
}

Welcome to this special issue of the Aotearoa New Zealand Social Work Journal. The theme for this edition is Child protection, the family and the state: critical responses in neoliberal times. Neoliberalism is becoming a ubiquitous word; aptly described as overused and over stretched (Gray et al., 2015) and employed "usually by a certain kind of critic, to characterise everything from a particular brand of free-market political philosophy and a wide variety of innovations in public management to patterns and processes found in and across diverse political spaces and territories" (Dean, 2014, p.150). Neoliberalism as a term does however capture the essence of some pernicious directions in family policy, both here and globally. In this special issue, we use it to refer to several key themes that increasingly frame the relationship of the state to the family in Aotearoa New Zealand.

Traditional liberalism promoted the aims of constant economic growth, consistent profits and the accumulation of capital over time as natural outcomes of a free market - free to respond to the drivers of supply and demand. Neoliberalism contains many aspects that depart from this purist ideal - particularly that, far from reliance on supply and demand, manipulation of the market is required to maintain economic growth (Harvey, 2005). This serves powerful vested interests, while operating punitive and tightly controlled policies towards those most affected by withdrawal of the social and economic protections of earlier times (Harvey, 2005; Wacquant, 2009). Neoliberal economic systems tend to result in redistributive mechanisms that exacerbate inequality, create more precarious work lives for many citizens, and are characterised by an upsurge in get tough social policy approaches such as imprisonment and punitive interventions. Garrett (2010) states that in social work and social service provision, while the state seems to promote freedom, it is "in fact interventionist in ensuring an institutional framework to support a competitive market of service providers and an active approach to public management despite its claims of free market orientation" (in Gray et al, 2015, p. 370).

Such a system contains many dominant doxa - discourses which appear natural and normal - about the causes of human behaviour and how we should respond when the actions of individuals or groups deviate from prescribed social norms (Bourdieu,1977). Crossley (2015) points out that doxa promoted by governments are especially persuasive, but should be viewed as culturally specific to particular, in this case neoliberal, societies. Within the pervasive and normalised worldview promoted by neoliberalism, those who fail to obtain wealth, health and independence from the state are viewed as personally responsible for their own perceived shortcomings. Accordingly, the role of social work is conceived as managing and responsibilising those who cannot or will not become self-reliant (Houston 2013). In turn, if social work services (and practitioners by implication) cannot obtain these preferred outcomes, they are also subject to blame (Houston, 2013). The implementation of market principles and processes has become widespread in social policy reforms here in Aotearoa, with threads of individualisation and responsibilisation running through both welfare and child protection reforms (Rose, 1999, Keddell, 2016). Schram (2012) identifies the pattern behind these developments when he comments that neoliberalism is "best understood as a re-envisioning of the relationship of the state to the market, granting greater leeway to markets to operate without government restrictions,
AOTEAROA NEW ZEALAND SOCIAL WORK 28(2), 1-6. 
while marketising state programs so they themselves operate in market-compliant ways while getting clients to do the same" (p.67). Increasingly, large corporations are involved in delivering what once were public sector services, combined with increasingly restrictive and tightly controlled legislation governing the social work workforce. This may challenge practitioners' abilities to practice in ways that align with their values (Garrett, 2010).

Other themes in social service provision in neoliberal times include an increase in the use of technology to both surveil clients and retain control of practitioners, as well as delivering increasingly standardised and commodified services (Garrett 2010). Houston (2013) considers the impact of neoliberalism on social policy reform, noting that neoliberalism also leads to the increasing promotion of psychological explanations for human problems, negating their social genesis. Psychologising social problems tends to result in responsibility being placed onto individuals and their families for socially caused distress, as well as highly targeted, rather than universal service provision.

Individual members of the underclass are blamed personally for their welfare dependency and collectively for social instability and economic decline. In addition, neoliberal agents deploy this discourse to justify and garner support for policy directions that 'deal with' this enemy and thereby remove the impediment to the full flowering of the neoliberal social imaginary. (Hackell, 2016, p.4)

Many of these key themes can be traced in the social policy developments here in Aotearoa New Zealand over the last five years. Our welfare reform was premised on the idea that that the problem was "benefit dependency" (not poverty), caused by people's own unwillingness to work, and the solution was more active casework approaches, sanctions and obligations: an example of the new punitiveness described by Garrett (2010) (Welfare Working Group, 2011). The social investment approach underpinning it is operationalised in policy via mechanisms focused solely on reducing the costs of benefit provision; that is, reducing the numbers of people on benefits rather than investment in improving the health, income and educational outcomes of people accessing income benefits. Such a narrow interpretation of social investment lays bare its ideological foundations.

The vulnerable children's reform showed more of the 'get tough' approach. Its primary focus both in legislation and the Children's Action Plan was on increasing methods of surveillance and targeting by promoting stringent safety checks of professionals, information sharing and prediction as ways to respond to child abuse and neglect. These latter two were operationalized via the implementation of Children's Teams, the vulnerable kids information system and trials of predictive risk models. Practitioners have been subjected to the get tough approach by being exhorted to take more responsibility, for example the lead professionals in Children's Teams are expected to take exclusive responsibility for child outcomes (Ministry of Social Development, 2012b). The ecological causes of abuse and harm impacting on families were left untouched. Structural conditions such as poverty and even family level influences were carefully excised from the dominant doxa of causes or target problems for change. Problems were narrowly constructed as outcomes of individual behaviour. What has improved is the ability of the state to surveil both practitioners and citizens, with important human rights debates around privacy and effectiveness muted.

The neoliberalisation of the welfare and child protection systems in Aotearoa New Zealand are therefore well on track, and the New Zealand mainstream media and government policy work jointly to create neoliberal citizens who feel justified in their blame of beneficiaries and parents 
whose children are in contact with the child protection system. This garners widespread social support for services framed in such a way that it is difficult for them to do any more than police such parents (Hackell, 2016).

The current Aotearoa New Zealand (National) government explicitly denies the role of economic and cultural inequity in child protection policy. The White Paper for Vulnerable Children (Ministry of Social Development, 2012a) is prefaced by a clear statement from the (former) Minister of Social Development Paula Bennett:

Though, I acknowledge the pressure that financial hardship puts on families, that is never an excuse to neglect, beat, or abuse children. Most people in such circumstances do not abuse their children, and I cannot tolerate it being used as a justification for those who do. (Ministry of Social Development, 2012, p.2)

This position became more entrenched in our latest review of Child Youth and Family (Ministry of Social Development, 2015); its talk of social investment, forward liability, single points of accountability, direct purchasing and building markets clearly reflect the neoliberal drive to instill marketderived principles, efficiency mechanisms, goals and methods of accountability into social services. Further, the focus on trauma as a guiding principle, as Houston notes above, negates the social context of family life and its struggles, and may also obscure the culturally contested nature of "good parenting". In concert with a "child focused" doxa, the impact of neoliberalism and social investment logics serve to further make invisible the impacts of social conditions on parent's lives, as well as negating the impact of often painful parental life histories. For Māori, the lack of acknowledgement of heightened exposure to poverty and the ongoing effects of colonisation's material and discriminatory legacy is likely to exacerbate conservative interventionism in this context even further. Hackell observes this when she notes that:
Constructing the problem in terms of parenting places the blame on individual parents and implicates culturally based parenting practices. Elevating the role of parental psychology and culture obscures the role of social structural disadvantage and denies any sense of social responsibility. (Hackell, 2016, p.10)

Such a narrow conception of "child trauma" excised from the family context can lead to the most intrusive intervention - child removal - without efforts to reduce the stressors impacting on parenting first (Featherstone et al., 2014).

Interestingly, these logics of responsibility create differential outcomes for different groups of children - resulting in some improvements for children permanently removed into the care system. Responsibility for their outcomes is accepted as within the remit of the state, and recognition of the costs accruing to the state from their status as disadvantaged future citizens is leading to increasing resources for this group of children. For children and their families who have some contact with the child protection system, but are not taken into care, the doxa are very different: they are exhorted to take responsibility for all aspects of their lives despite the increasingly challenging structural conditions related to poverty, unaffordable housing and social stigma. Prevention services are offered, but if deemed unsuccessful, then removal of children to permanent care should be undertaken at the "earliest opportunity" (Expert Panel, 2015, p.7).

The impressive range of perspectives in this special issue describe many of these themes in specific locations and with specific populations, tracing the shape-shifting nature of neoliberal forces as they adapt themselves into a variety of contexts (Garrett, 2010). We celebrate local and international writing in this edition. This diversity offers a sense of common experience which enriches and deepens our understanding of the nature of the neoliberal project and speaks of 
opportunities to collaborate on issues that are global in nature. It also offers insight into unique local challenges.

We begin with a Commentary by Nigel Parton who usefully outlines the features of what he terms the authoritarian neoliberal turn and the impact of this political development for child protection services in the UK. His commentary offers a considerable challenge to social workers about the work being asked of us as employees/servants of an increasingly authoritarian, coercive, muscular state - to be "directive, supervisory and disciplinary."

Michael O'Brien continues this discussion with his view of how the neoliberal framework is informing and shaping social service delivery in New Zealand. He looks at a triplet of key terms - investment, vulnerable, and outcomes - and provides analysis of their meanings and implications for social work, and for the people we work alongside. He ends with a series of pointed questions and challenges to the profession; how do we intend to work ethically, with attention to bi-cultural, multicultural and Treaty obligations? These questions are critical; there is significant pressure on social workers and their agencies created by neoliberal drives, not the least of which is the overriding focus on pre-ordained quantitative outcomes. His treatment of the concept of vulnerability is particularly timely given the public debate around the use of this term to best describe children in need.

From a service user perspective, Kerri Cleaver offers a powerful analysis of her experience as a young Māori woman leaving the care system in New Zealand, not knowing at the time the impact neoliberal policies were having on her experience, or on the common experience of all care leavers. New Zealand policies placed responsibility for the well being of young people in state care squarely on the young people themselves despite strong human rights, human development and social expectation rationales justifying continued care and oversight of young people as they approach adulthood. She develops a comprehensive critique of the recent history of care leaving policy and practice in Aotearoa New Zealand and in comparable states internationally. She presents some recommendations for policy and practice with young people, including legislative change, financial and service provision and dedicated research. She emphasises the experience and voice of Māori as critical in this context - as it is to understanding and framing responses to the implications of the neoliberal narrative more generally in Aotearoa -New Zealand.

To further the focus on the impact of policy on service users, (first name) Lynda Sawyers applies Beddoe and Maidment's (2009) critical intersections model to analyse the government's Community Investment Strategy and to develop an appropriate social work response. She argues that social workers are ethically obligated to respect and uphold the rights of service users in resisting the potentially oppressive implications of this policy initiative. Her creative application of critical theory helps reposition social work as a way to resist neoliberal concepts implicit in the CIS.

Sarah Martin traces the development of one of the recent amendments to the Children, Young Persons and their Families Act 1989 that was part of the Vulnerable Children's legislative reform package. She discusses the amendment giving increased prominence to the principle that the best interests of the child shall be the paramount consideration in care and protection proceedings. She applies best practice principles of rational - comprehensive policy change to critically evaluate the process of this legislative amendment, and finds it wanting in several ways. She identifies a blatant lack of transparency, a lack of consultation with key stakeholders and a particular lack of consultation with iwi Māori, over a change that clearly challenges the rights of whānau hāpu and iwi enshrined in the original Act. The pattern of policy change she identifies is for such changes to be driven by political expedience and populist discourses, and to be written by a policy oligarchy - a 
small group of elite policy makers within the MSD with limited accountability to service users or other stakeholders. This analysis has serious implications for the forthcoming legislative changes relating to the child youth and family review.

The issue of outcomes is addressed by Mike Webster and David McNabb in their article about New Public Management (NPM) philosophy, its role in providing a mechanism for organizational accountability, and the challenge of providing best social work practice within this context. These authors suggest priority be given to the interaction between social workers and the people they serve, a focus on the common factors and relational approach to practice; a reclamation of the core relationship with families. They promote a belief that achieving this contributes wholly to the concept of "accountable practice."

Linda Haultain and co-authors examine the impacts of neoliberal conceptualisations on how the child protection project is framed, and how this might relate to work with pregnant women in the women's health domain. They argue that the increasing focus on being 'child centred' within a neoliberal environment creates tensions in a practice context where the wellbeing of the mother, often extremely marginalised, cannot be viewed separately from the wellbeing of the child. In this situation, her findings show the need for practitioners to maintain a focus that promotes and cares for the rights and wellbeing of both mother and baby. She argues they should be viewed as conjoined within a relational web of whanau, despite the ideological threat to this stance: namely the extreme individualisation of children in neoliberal environments, one that prefers to separate the interests of mother and child, painting one as deserving and one as not.

This national experience intersects with an environment of economic and cultural inequity written about in this issue by our overseas contributors. Ian Cummins discusses the parallel experience of neoliberal policy reform in the UK, reminding us again of the need to consider structural factors and to remember the punitive aspect of neoliberal ideology and culture, its focus on individual responsibility for life experience and denial of the role of our failed and failing social care systems of education, health and housing. Cummins asks us to consider the role we as social workers are playing in this landscape, reinforcing points made by Mike O'Brien and Nigel Parton - asking how we can justify our role in the increasingly punitive and coercive neoliberal state. He argues that an understanding of the work of the French sociologist Loic Wacquant may provide the basis for the rediscovery of practice driven by respect for human dignity.

Munyaradzi Muchacha and co-authors bring a fascinating perspective from Zimbabwe, outlining the specific historical context of that country as it has moved from a broadly socialist orientation to a neoliberal one since 1991. In combination with the Mugabe regime, high poverty and the impact of HIV / AIDS, neoliberalism has been devastating, particularly for the immense numbers of orphaned children (about 1 million orphans in a population of 13 million). This has resulted in extreme challenges for children, their remaining kinship caregivers, and social workers. The authors identify the impacts of neoliberalism in that context, as reductions in social expenditure has resulted in stringent means testing for social safety nets, and reduction of the civil service wage bill - so that both service users and social workers are drastically affected. The authors challenge social workers to use developmental social work as a model appropriate for these conditions, as it focusses on building the capacities of kinship carers, engaging in advocacy and actively contributing to the social policy-making process. Multiple points of engagement with policy making and service users, they argue, is the only way for social workers to respond to both the politics dictating resource provision as well as the micro concerns of service users.

In conclusion, the articles offered in this edition are all, in various ways, concerned 
with the quest for social justice in challenging times. The collective analysis of current political, economic, social issues and events serves to develop and illustrate the reach and maturity of our profession; to cast a critical eye over the implications of neoliberal social change for the children and families most fiercely impacted by it. We thank the contributors for their hard work, their ideas and their questions - without new questions we will never find new answers. And finally, thank you to the social work practitioners who are reading this journal. You are encouraged to adapt and critique the ideas offered by contributors and to apply them in the development and delivery of effective and compassionate social work practice with children and families.

\section{References}

Beddoe, L., \& Maidment, J. (2009). Mapping knowledge for social work practice: Critical intersections. Melbourne: Cengage.

Bourdieu, P. (1977). Outline of a theory of practice. Cambridge: Cambridge University Press.

Crossley, S. (2015). Realising the (troubled) family', 'crafting the neoliberal state' Families, Relationships and Societies. doi: doi.org/10.1332/204674315X14326465757666

Dean, M. (2014). Rethinking neoliberalism. Journal of Sociology, 50(2), 150-163.

Featherstone, B., White, S., \& Morris, K. (2014). Re-imagining child protection: Towards humane social work with families. Bristol, UK: Policy Press.

Garrett, P. M. (2010). Examining the 'conservative revolution': Neoliberalism and social work education. Social Work Education, 29(4), 340-355.

Gray, M., Dean, M., Agllias, K., Howard, A., \& Schubert, L. (2015). Perspectives on neoliberalism for human service professionals. Social Science Review(June), 368-392.
Hackell, M. (2016). Managing anxiety: neoliberal modes of citizen subjectivity, fantasy and child abuse in New Zealand. Citizenship Studies, 1-16. doi: 10.1080/13621025.2016.1204270

Harvey, D. (2005). A brief history of neoliberalism. Oxford: Oxford University Press.

Houston, S. (2013). Social work and the politics of recognition. In M. Gray \& S. Webb (Eds.), The new politics of social work (pp. 63-75). Basingstoke: Palgrave.

Keddell, E. (2016). Child protection reform and welfare reform in aotearoa new zealand: Two sides of the same coin? In J. Maidment \& E. Beddoe (Eds.), Social policy for social work and human services in aotearoa new zealand: Diverse perspectives. Christchurch: Canterbury University Press.

Ministry of Social Development (2012a). White Paper for Vulnerable Children: Vol. 1. Wellington, New Zealand: Ministry of Social Development. Retrieved from http:// www.msd.govt.nz/documents/about-msd-and-our-work/ work-programmes/policy-development/white-papervulnerable-children/white-paper-for-vulnerable-childrenvolume-1.pdf

Ministry of Social Development (2012b). Children's action plan: Identifying, supporting and protecting vulnerable children. Wellington, New Zealand: Mnistry of Social Development. Retrieved from http://childrensactionplan. govt.nz.

Modernising Child Youth and Family Expert Panel (2015). Expert panel final report: Investing in New Zealand's children and their families. Wellington, New Zealand: Ministry of Social Development. Retrieved from https://www.msd.govt.nz/documents/about-msd-andourwork/work programmes/investing-in-children/investingin-children-report.pdf

Rose, N. (1999). Powers of freedom. Cambridge: University Press.

Schram, S. (2012). Welfare professionals and street level bureaucrats. In M. Gray, J. Midgely \& S. Webb (Eds.), The Sage handbook of social work (pp. 67 - 80). London: Sage.

Wacquant, L. (2009). Prisons of poverty. Minneapolis: University of Minnesota Press.

Welfare Working Group. (2011). Reducing long term benefit dependency: Recommendations. Wellington: Welfare Working Group Secretariat.

Emily Keddell, University of Otago, Deb Stanfield, Wintec and lan Hyslop, University of Auckland 